\title{
Advanced Clear Cell Renal Cell Carcinoma
}

National Cancer Institute

\section{Source}

National Cancer Institute. Advanced Clear Cell Renal Cell Carcinoma. NCI Thesaurus.

Code C159562.

A clear cell renal cell carcinoma that has spread extensively to other anatomical sites or is no longer responding to treatment. 